\title{
The effect on perfectionism on burnout: An investigation on marble employees ${ }^{1}$
}

\section{Mükemmeliyetçiliğin tükenmişlik üzerine etkisi: Mermer çalışanları üzerine bir araştırma}

\author{
Esra Burcu Bulgurcu Gürel ${ }^{2}$ \\ Funda Kıran ${ }^{3}$ \\ Özlem Çetinkaya Bozkurt ${ }^{4}$
}

\begin{abstract}
${ }^{1}$ This article is an extended and improved version of the paper published in the proceedings of 7th Organizational Behavior Congress hosted by Burdur Mehmet Akif Ersoy University.
\end{abstract}

\section{Assoc. Prof. Dr., Muğla Sitkı Koçman University, Muğla, Türkiye, esragurel@mu.edu.tr,}

ORCID: 0000-0002-4468-880X

${ }^{3}$ Res. Asst., Burdur Mehmet Akif Ersoy University, Burdur, Türkiye,

fkiran@mehmetakif.edu.tr,

ORCID: 0000-0002-6456-2497

4 Prof. Dr., Burdur Mehmet Akif Ersoy University, Burdur, Türkiye, ozlemcetinkaya@mehmetakif.edu.tr,

ORCID: 0000-0002-6218-2570

\section{Corresponding Author:}

Funda Kiran,

Burdur Mehmet Akif Ersoy University, Burdur, Türkiye,

$\underline{\text { fkiran@mehmetakif.edu.tr }}$

Submitted: $23 / 12 / 2020$

Revised: 17/02/2021

Accepted: 9/03/2021

Online Published: 25/03/2021

Citation: Bulgurcu Gürel, E.B., Kıran, F. \& Çetinkaya Bozkurt, F., The effect on perfectionism on burnout: An investigation on marble employees, bmij (2021) 9 (1): 110-125, doi:

https://doi.org/10.15295/bmij.v9i1.1734

\begin{abstract}
This study examines the relationship between the traits of a perfectionist personality and burnout Perfectionists constantly set extremely high standards and make great efforts to achieve. In this regard, it can be stated that perfectionism is a concept that is closely related to burnout. The sample consisted of 158 employees working in a marble enterprise operating in the province of Burdur. As a result of the research, all hypotheses were supported. A statistically positive and significant relationship between the variables in the model was found. In other words, a significant and positive relationship was found between self-oriented perfectionism and emotional exhaustion, depersonalization, and personal accomplishment, which are the sub-scales of burnout.
\end{abstract}

Keywords: Perfectionism, Self-oriented perfectionism, Burnout

Jel Codes: D23, M19

Öz

Bu çalışmada mükemmeliyetçi kişilik özelliği ile tükenmişlik arasındaki ilişki araştırılmaktadır Mükemmeliyetçiler, sürekli olarak kendilerine yüksek hedefler belirlemekte ve başarılı olmak için oldukça büyük bir çaba harcamaktadır. Bu açıdan bakıldığında mükemmeliyetçiliğin, tükenmişlikle yakından ilişkili bir kavram olduğu ifade edilebilir. Araştırmanın örneklemini Burdur ilinde faaliyet gösteren mermer işletmelerindeki 158 çalışan oluşturmaktadır. Araştırma sonucunda tüm hipotezler desteklenmiş ve modeldeki değişkenler arasında istatistiksel olarak pozitif ve anlamlı bir ilişki bulunmuştur. Bir başka ifadeyle; mükemmeliyetçiliğin kendine yönelik mükemmeliyetçilik alt boyutu ile tükenmişliğin duygusal tükenme, duyarsızlaşma ve kişisel başarı alt boyutları arasında anlamlı ve pozitif yönde bir ilişki saptanmıştır.

Anahtar Kelimeler: Mükemmeliyetçilik, Kendine Yönelik Mükemmeliyetçilik, Tükenmişlik

IEL Kodlari: D23, M19 


\section{Introduction}

Perfectionism can be expressed as a combination of solid adherence to extremely high standards and a self-critical perspective (Hill and Curran, 2015, p.270). In this respect, perfectionism can be considered a highly effective and mobilizing force; however, if the effort fails, it ultimately lays the foundation for a robust psychological challenge (Hill and Appleton, 2011, p.696). It is seen in the literature that perfectionism has been researched in many different occupational groups. For example; athletes (Anshel and Mansouri, 2005), students (Rice and Dwello 2002; Stoeber and Eysenck 2008), teachers (Stoeber and Rennert, 2008), artists (Mor et al. 1995), police officers (Hralbuik, 2009), cooks (Eren and Günlü Küçükaltan, 2017) career mothers (Mitchelson and Burns 1998), supervisors and managers of hotels (Kanten and Yeşiltaş 2015, p. 1367), psychotherapists (Forney et al.1982 cited by D'Souza et al. 2011), bankers (Kakırman and Birsel 2015) have been studied. Despite some views that positively evaluate perfectionism, according to Flett and Hewitt (2006), constantly striving for perfectionism later results in a lack of motivation because perfectionist individuals attach to hard-to-reach goals and have an irrational belief to be successful. This condition always leads the perfectionists to criticize themselves constantly and focus excessively on their inadequacies, especially if there is a significant difference between their goals and realized goals. This condition not only increases the level of stress but also increases the burnout risk (cited by Aghdasi, 2014, p. 30). It is stated that perfectionism is a personality trait closely related to stress and burnout. The personality structures of employees have a significant effect on their probability of experiencing burnout. It is stated that individuals who are idealistic, perfectionist, goal-oriented, challenging, competitive, critical, make an effort to complete the tasks on time, responsible, have expectations that are difficult to meet are at a greater risk of burnout (Ardıç and Polatç1 2009, p. 23). In recent years, there has been an increase in academic studies investigating the effects of perfectionism on working life. Some results of these studies are that concepts such as workaholicism (Stoeber et al., 2013; Tziner and Tanami, 2013) and burnout (Childs and Stoeber 2010) are closely related to perfectionism. Also, the other researchers mentioned that perfectionism creates low job satisfaction because it triggers intolerance behaviours against conflicts in business life (Fairlie and Flett 2003; Wittenberg and Norcross 2001).

Moreover, efficiency and productivity are low when it provides high-quality performance (Sherry et al. 2010; Stoeber and Eysenck 2008) is the other finding. In this study, the relationship between perfectionism and burnout on blue-collar workers, which has limited studies in the literature, was investigated. The relatively high burnout rate in the marble sector is the main factor in choosing this sector. The results of Demirezen and Şenol's (2020) study on the stress level and burnout in the marble sector show that almost half of the participants have a burnout level of three points or more.

Based on these findings, the reasons for burnout were emphasized in the study, and as a result of the marble factories' emphasis on perfectionism in their working principles, the relationship between the two concepts was examined.

\section{Conceptual framework}

\section{Perfectionism}

Perfectionism is described as a personality trait expressed as setting extremely high-performance standards for oneself and being extremely critical when evaluating one's behaviour (Hewitt and Flet, 2004). The roots of perfectionism research are based on psychodynamic theory. Horney (1950), one of the well-known psychologists on the subject, described perfectionism as the tyranny of the should and as a highly neurotic personality trait devoid of any positive qualities. According to Horney (1950), if a neurotic person behaves incompatibly with his perfect self, he will not tolerate his mistake and not forgive himself. He begins to move away from himself because of the sanctions he imposes on himself for the image he idealizes (Horney 1950). Adler (1956), another critical psychologist, states that perfectionism is innate, and unlike Horney, it should be evaluated as two-dimensional, positively, and negatively. From this point of view, it can be stated that Adler emphasized the multi-dimensional nature 
of perfectionism for the first time. Burns $(1980$, p. 37) stated that perfectionists set unrealistic standards and make great efforts to reach these standards.

On the other hand, Hollander (1965) defines perfectionism as an individual's expectation of higher quality performance from himself and others (cited by Demirci and Çepikkurt, 2018, p.1253). Although there is no generally accepted definition of perfectionism in literature, there are some essential qualities of perfectionism. Perfectionism can be identified as the tendency to set highly high-performance standards, strive to excel in all areas of life, engage in all-or-nothing thinking, and generalize failures (Kakırman and Birsel, 2015, p.110).

Some authors discuss perfectionism as a positive personality trait in the relevant literature, while others approach perfectionism negatively, just like Horney (1950). According to Kottman and Ashby (2000), perfectionism is a performance-enhancing trait. Cheerful perfectionists do not experience high anxiety and stress to achieve high standards, and if they fail to achieve their goals, they are not destroyed (as cited by Cenkseven Önder and Kırdök, 2009, p.264). Individuals showing positive traits of perfectionism are aware of their abilities. Therefore, they set more realistic and achievable goals for themselves. Hence, adaptive perfectionists are more likely to meet the standards they set for them (Büyükateş, 2018).

On the other hand, Burns (1980, p. 37), who emphasizes perfectionism's negative aspects, describes perfectionists as difficult, unreasonable, striving to reach the high standards they set, or obsessively sticking to impossible goals and measuring their worth only with productivity and success. According to Burns, these people have difficulties achieving their goals due to this tendency, and their performances are damaged with this situation. Similarly, Shafran et al. (2002) considered perfectionism as the negative self-evaluation or self-criticism that individuals experience when they cannot reach the high standards set. According to the authors in question, perfectionists were identified as people who pursue high-ultimate goals, set high-performance standards and strive for perfection.

While perfectionism was previously considered as a one-dimensional concept in studies, it is seen that it is discussed as a multi-dimensional concept in future studies (Frost and et al., 1990; Hewitt and Flett, 1991). Frost et al. (1990) examined perfectionism as a multi-dimensional structure in six sub-scales: high personal standards, concern over mistakes, doubts about actions, excessive parental criticism, high parental expectation, and order. The Almost Perfect Scale developed by Slaney et al. (2001) consists of sub-scales, including high standards, order, and discrepancy. On the other hand, Hewitt and Flett (1991) described three dimensions of perfectionism: self-oriented perfectionism, other-oriented perfectionism, and socially prescribed perfectionism. Self-oriented perfectionism involves setting exceptionally high standards and goals for oneself and constantly striving to avoid failure. Self-oriented perfectionists blame themselves in case of any failure. The other-oriented perfectionists impose unrealistic and difficult standards to reach for significant others and expect them to achieve these goals. They blame the other for the failure. Socially prescribed perfectionism believes that the significant others have unrealistic standards and expectations, and they try to attain these standards and goals and thus when they fail to meet these expectations, they blame themselves for the failure (Hewitt and Flett, 1991, p. 457). This study is based on Hewitt and Flett's (1991) approach.

\section{Burnout}

Herbert Freudenberger (1974) first used the term burnout to describe a particular type of work stress. Freudenberger used this term to describe slowly progressing emotional discharge, declining motivation, and work commitment of young employees working in a clinic as volunteers. The author defines burnout as depletion of internal resources due to failure, loss of energy and power, and unfulfilled desires (Maslach et al., 2001, p. 399; Cakınberk, 2011, p.6826). Burnout is different from temporary fatigue that disappears after a specific rest period and can occur at different work-life stages (Çimen, 2000, p.6). Burnout is not a psychological state of emotion that occurs suddenly. Employees' burnout syndrome can be expressed as an emotional state that occurs when exposed to long-term and 
intense work stress caused by excessive work demands (emotional and physical) at work (Çiçek and Aknar,2019, p.1237).

Burnout is an adverse emotional reaction developed by individuals exposed to long-term high stress in the workplace (Anvari et al., 2011, p. 115). Burnout syndrome is the emotional exhaustion of employees, an exhibition of an indifferent attitude towards their work and the people they are responsible for, and feeling inadequate to achieve goals. Maslach et al. (2001, p. 402) define burnout as "the state of fatigue and exhaustion that occurs with the decrease of physical and emotional energy which other people can easily observe". According to Maslach and Jackson (1981, p. 99), the concept of burnout is comprised of three dimensions that indicate feelings of emotional exhaustion, depersonalization, and personal accomplishment. Sensory burnout is the most critical and most analyzed dimension of burnout, which is an extraordinarily complex process (Lee and Ashforth, 1993, p. 303). Emotional exhaustion refers to the "decrease in the emotional and physical sources of the individual". The feelings of fatigue, exhaustion, loss of energy, and emotional weariness are observed with the individual who experiences emotional exhaustion (Maslach et al., 2001, p.402-403). Depersonalization refers to the interpersonal dimension of burnout syndrome. This dimension is typical in individuals who are constantly in contact with people while doing their work. Depersonalized individuals behave strictly and indifferently with customers and other people with whom they have business relationships (Wright, Bonett, 1997, p.492). Employees can exhibit a distant, careless, and sarcastic attitude towards both the people they serve and the institution they work for, and they do not feel disturbed by this situation (Çimen, 2000, p. 6). A person's tendency to evaluate himself negatively is defined within the dimension of personal accomplishment. An emotionally worn and exhausted individual is unable to fulfil the requirements of his job and feels inadequate. An individual who feels a decrease in his success and motivation considers himself as incompetent in his job. The individual who experiences a feeling of personal failure thinks that he has not made any progress in his job, that the effort he has spent is in vain and thus feels guilty (Maslach et al., 2001, p.403).

\section{The relationship between perfectionism and burnout}

Perfectionism is a personality trait closely related to stress and burnout. Employees' personality traits have a significant impact on the possibility of experiencing burnout. In terms of personality structure, idealistic, perfectionist, goal-oriented, combative, competitive, critical, hasty, striving to complete tasks on time, faithful to their word, and responsible individuals with hard-to-meet expectations are at greater risk of exhaustion (Ardıç and Polatçı 2009, p. 23). Perfectionists are under enormous pressure to be successful because they think they and other people should live in the high standards they set. From this perspective, it is not surprising that perfectionism is related to high stress and burnout levels (Stoeber and Rennert, 2008, p. 38). According to Hall (2006), perfectionism may cause adverse outcomes like the development of maladaptive affective responses, declines in physical health, and the development of burnout.

The studies' results explaining the relationship between perfectionism and burnout in the literature show a very complex view. Forney et al. (1982) mentioned that psychotherapists reporting burnout stated common beliefs that reflect perfectionism (cited by D'Souza et al., 2011, p.19). It was concluded in the study conducted by Çam et al. (2014, p. 312) on university students that stress increased in perfectionist individuals and that increasing stress caused burnout. In a study conducted by Balevre et al. (2012) on nurses, a positive and significant relationship was found between burnout and perfectionism. Badawy and Mohamad (2015, p. 7) found a significant correlation between perfectionism and burnout in doctors' study. The study determined a significant and positive relationship between perfectionist thoughts and emotional exhaustion, and total burnout score. Fry (1995) emphasized those female executives and investigated the effect of perfectionism on stress. According to results, stress levels a significant moderator. When workplace stress increased, women with higher perfectionism showed negative physical health symptoms and increased burnout (cited by D'Souza et al. 2011, p.18). 
Furthermore, Childs and Stoeber (2012, p.347) found that socially prescribed perfectionism predicted increases in exhaustion and cynicism over time with a sample of 195 school teachers in the UK. Besides, their findings indicate that individual differences in socially prescribed perfectionism may contribute to stress and burnout levels in the workplace. Mitchelson and Burns (1998), with a small sample of 67 career mothers, found that socially prescribed perfectionism was associated with higher levels of burnout (exhaustion, cynicism) at home and work (Childs ve Stoeber, 2010, p.271.) Lazarus (1999) revealed that maladaptive forms of perfectionism caused more threatening perceptions of stress, and this perception effect burnout level. Demirci and Çepikkurt (2018, p. 1252) found in their study that athletes with an obsessive passion for sports and tendencies of maladaptive perfectionism were prone to burnout. Zhang et al. (2007) also found a positive relationship between maladaptive perfectionism and burnout in college students' study. Gould et al. (1996) revealed that athletes experiencing burnout exhibited neurotic perfectionism (cited in Tashman et al., 2010, p. 197-198). Mitchelson and Burns (1998) detected a significant relationship between social perfectionism and burnout.

On the other hand, Hill and Curran's (2015, p.269) meta-analysis study revealed that perfectionistic strivings had slight negative or non-significant relationships with overall burnout and symptoms of burnout. By contrast, perfectionistic concerns displayed medium-to-large and medium positive relationships with overall burnout and symptoms of burnout. In the study conducted by Sakal and Yildız (2017, p. 38), it was concluded that academicians' increased maladaptive perfectionism causes increased emotional burnout. Besides, it is observed that adaptive perfectionism leads to higher psychological well-being levels, and maladaptive perfectionism causes lower psychological well-being levels. Kakırman and Birsel (2015, p. 107) found a negative and significant relationship between successoriented perfectionism and burnout in their study on bank employees.

\section{Research method}

\section{The purpose and importance of research}

In this study, the relationship between perfectionism and burnout was investigated in the sample of marble sector employees. In the literature, the relationship between perfectionist personality trait and burnout has been explored on different sample groups, including especially athletes (Appleton et al.2009; Hill et al., 2010), teachers (Stoeber and Rennert, 2008; Childs and Stoeber 2012, p.347), bank employees (Kakırman and Birsel, 2015), students (Cho and Kang, 2017; Zhang et al. 2007; Çam et al. 2014, p. 312), nurses (Balevre et al. 2012; Çam et al. 2014), doctors (Badawy and Mohamad, 2015, p. 7), executives (Fry, 1995 cited by D'Souza et al. 2011), academicians (Sakal and Ylldiz, 2017, p. 38). However, there is very little work done on a sectoral basis, especially blue-collar workers. The study will contribute to the literature in this respect.

\section{Data collection tools}

The questionnaire technique, one of the quantitative research techniques, was used during the data collection. The questionnaire consists of three parts. In the first part, Maslach's Burnout Inventory was used to measure burnout in organizations. Maslach's Burnout Scale was developed by Maslach and Jackson (1986) and adapted into Turkish by Ergin (1992). The inventory with 22 items in total is a 5Likert type scale.

In the second part of the questionnaire, the "Multi-dimensional Perfectionism Scale" was administered. The scale developed by Hewilt and Flett (1989) is a 7-point Likert type with 45 items. The scale was adapted to Turkish by Oral (1999). In the last part of the questionnaire, there are questions about the demographic characteristics of the participants. In the questionnaire form, adhering to the original forms of the scale, both 5-point and 7-point Likert scales were used. Measurements were carried out by taking arithmetic averages. 


\section{A sampling of the study}

The research population consists of the employees working in the marble enterprises operating in the provinces and districts of Burdur. According to the information obtained from the official website of the Burdur governorship, approximately 9000 people work in marble enterprises (Burdur Valiliği, 2019). The convenience sampling method was used in the study. Both the consent of the employers and the employees have been obtained for conducting the surveys. Between May and June 2019, employees working in different marble factories were interviewed. For safety reasons, the surveys were conducted during lunch breaks of employees. The surveys were done face-to-face. Since the data were collected before January 1, 2020, ethics committee approval was not obligatory. A total of 174 employees filled out the questionnaire. After removing the extreme values, the analyzes were carried out by taking into account the 158 employee questionnaires.

Table 1: Statistical Information about the Demographic Characteristics of the Sampling

\begin{tabular}{|c|c|c|c|c|c|}
\hline Gender & Frequency & Percentage (\%) & Marital Status & Frequency & Percentage (\%) \\
\hline Female & 28 & 17.7 & Married & 110 & 69.6 \\
\hline Male & 128 & 81.0 & Single & 37 & 23.4 \\
\hline Missing Value & 2 & 1.3 & Missing Value & 11 & 7.0 \\
\hline Ages & Frequency & Percentage (\%) & $\begin{array}{l}\text { Monthly } \\
\text { Income }\end{array}$ & Frequency & Percentage (\%) \\
\hline $18-24$ & 16 & 10.1 & Below 1600 TL & 16 & 10.1 \\
\hline $25-31$ & 25 & 15.8 & $1600 \mathrm{TL}$ & 69 & 43.7 \\
\hline $32-38$ & 38 & 24.1 & Above $1600 \mathrm{TL}$ & 69 & 43.7 \\
\hline $39-45$ & 31 & 19.6 & Missing Value & 4 & 2.5 \\
\hline $46-52$ & 12 & 7.6 & & & \\
\hline 53 and above & 7 & 4.4 & & & \\
\hline Missing Value & 29 & 18.4 & & & \\
\hline $\begin{array}{l}\text { Educational } \\
\text { Background }\end{array}$ & Frequency & Percentage (\%) & $\begin{array}{c}\text { Work } \\
\text { Experience }\end{array}$ & Frequency & Percentage (\%) \\
\hline Elementary & 76 & 48.1 & Less than 1 year & 20 & 12.7 \\
\hline Secondary & 30 & 19.0 & $1-5$ years & 36 & 22.8 \\
\hline High school & 37 & 23.4 & 6-10 years & 47 & 29.7 \\
\hline $\begin{array}{l}\text { University } \\
\text { and above }\end{array}$ & 7 & 4.4 & $\begin{array}{c}11 \text { years and } \\
\text { above }\end{array}$ & 36 & 22.8 \\
\hline Missing Value & 8 & 5.1 & Missing Value & 19 & 12.0 \\
\hline
\end{tabular}

According to Table 1, the rate of males and married people in the sample is relatively high. $24.1 \%$ of them are between the ages of 32-38. Although the number of people with a salary of $1600 \mathrm{TL}$ and above is the same, they constitute $43.7 \%$ of the sample. $48.1 \%$ of the participants are primary school graduates, while 29.7\% have worked in the enterprise for 6-10 years. Employees with a salary below 1600 TL indicate different work arrangements such as part-time and job sharing.

\section{Research model and hypotheses}

\section{Self-oriented Perfectionism}

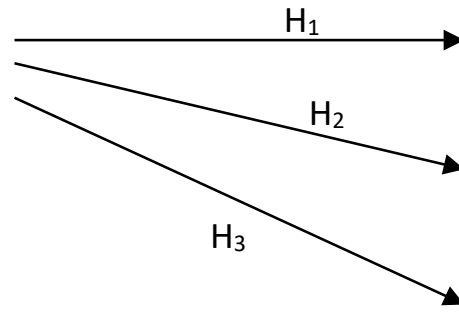

Emotional Exhaustion

Desensitization

Personal Success

Figure 1: Research Model 
Perfectionism is a personality trait that plays a vital role in stress and burnout. Studies reveal that perfectionism has some adverse psychological effects on individuals, such as depression, anxiety disorder, chronic insomnia, social phobia, panic disorder, eating disorder, and suicidal thoughts. Moreover, it is also stated that perfectionism leads to a chronic sense of failure, indecision, shame, and burnout. On the other hand, it is stated that personality traits such as type A personality, locus of control, self-esteem, and perfectionism play an essential role in the emergence of emotional exhaustion. Burnout syndrome is a weary and tiresome condition for the individual. Emotional exhaustion, which is the most critical component of burnout syndrome, occurs because of long-term stress exposure. Perfectionists feel tremendous pressure to become prominent and outclass. If the individual constantly feels a high demand for their sources, they face the risk of burnout. Appleton et al. (2009) and Chen et al. (2008) found a positive relationship between perfectionism and burnout in their studies conducted on students and athletes. The hypotheses created in the light of this information are as follows;

$\mathbf{H}_{1}$ : There is a statistically significant and positive relationship between self-oriented perfectionism and emotional exhaustion.

$\mathbf{H}_{2}$ : There is a statistically significant and positive relationship between self-oriented perfectionism and depersonalization.

$\mathbf{H}_{3}$ : There is a statistically significant and positive relationship between self-oriented perfectionism and personal accomplishment.

\section{Findings}

\section{Normality, reliability, and validity tests}

The normal distribution of the data given in the study was examined with Skewness and Kurtosis coefficients. Since the skewness and kurtosis values of the study are between +1.5 and -1.5 (Tabachnick and Fidell, 2013) (Table 2), it is seen that all variables show a normal distribution.

Table 2: Information of Variables' Skewness, Kurtosis, and Reliability

\begin{tabular}{ccccc}
\hline & Skewness & Kurtosis & $\begin{array}{c}\text { Nos. of } \\
\text { Expression }\end{array}$ & Cronbach Alfa \\
\hline Emotional Exhaustion & -0.418 & -0.498 & 9 & 0.912 \\
\hline Personal Accomplishment & 0.354 & -0.168 & 8 & 0.851 \\
\hline Depersonalization. & -0.480 & -0.235 & 5 & 0.781 \\
\hline Self-oriented perfectionism & -0.274 & -0.286 & 15 & 0.761 \\
\hline
\end{tabular}

Then, the reliability of measurement tools was examined. For the scale to be considered reliable, the Cronbach alpha reliability coefficient should be 0.70 and above (Gürbüz and Şahin, 2016, p. 325). However, as a result of the analysis, it was seen that the Cronbach alpha value of some variables was below 0.70 , and the sub-scales of other-oriented perfectionism and socially prescribed perfectionism were excluded from the analysis.

Factor analysis was performed to determine the construct validity of the scales. Table 3 presents information about burnout syndrome. First, the Kaiser-Meyer-Olkin (KMO) sampling adequacy criterion and Bartlett's Test of Sphericity were used. According to Table 3, values of (KMO $\geq 0.60 ; \mathrm{p}$ $<0.05$ ) are suitable for factor analysis (Gürbüz and Şahin, 2016, p. 319). Then the data were included in the factor analysis, and the scale was divided into three sub-scales as in the literature (Table 3). 
Table 3: Factor Analysis of Burnout Scale

\begin{tabular}{|c|c|c|c|}
\hline Burnout Scale & $\begin{array}{c}\text { Emotional } \\
\text { Exhaustion }\end{array}$ & $\begin{array}{c}\text { Personal } \\
\text { Accomplishment }\end{array}$ & Depersonalization \\
\hline I feel emotionally drained from my work & 0.729 & & \\
\hline I feel used up at the end of the workday & 0.745 & & \\
\hline $\begin{array}{l}\text { When I get up in the morning, I feel that I } \\
\text { cannot stand another day at work. }\end{array}$ & 0.839 & & \\
\hline $\begin{array}{l}\text { Working with people all day is really a strain } \\
\text { for me }\end{array}$ & 0.677 & & \\
\hline I feel burned out from my work & 0.796 & & \\
\hline I feel frustrated by my job & 0.819 & & \\
\hline I feel I am working too hard in my job & 0.593 & & \\
\hline $\begin{array}{l}\text { Working with people directly puts too much } \\
\text { stress on me }\end{array}$ & 0.528 & & \\
\hline $\begin{array}{l}\text { I feel like I am at the end of my rope and } \\
\text { burned out. }\end{array}$ & 0.788 & & \\
\hline $\begin{array}{l}\text { I can easily understand how people feel } \\
\text { about things }\end{array}$ & & 0.518 & \\
\hline $\begin{array}{l}\text { I deal very effectively with the problems of } \\
\text { the people I meet. }\end{array}$ & & 0.631 & \\
\hline $\begin{array}{l}\text { I believe I am positively making } \\
\text { contributions to other people's lives through } \\
\text { my work }\end{array}$ & & 0.660 & \\
\hline I feel very energetic & & 0.687 & \\
\hline $\begin{array}{l}\text { I can easily create a relaxed atmosphere } \\
\text { with people I meet because of my job. }\end{array}$ & & 0.791 & \\
\hline $\begin{array}{l}\text { I feel exhilarated after working closely with } \\
\text { people. }\end{array}$ & & 0.732 & \\
\hline $\begin{array}{l}\text { I have accomplished many worthwhile things } \\
\text { in this job. }\end{array}$ & & 0.708 & \\
\hline $\begin{array}{l}\text { In my work, I deal with emotional I } \\
\text { encounter problems very calmly }\end{array}$ & & 0.716 & \\
\hline $\begin{array}{l}\text { I feel I treat some people I meet as if they } \\
\text { were objects }\end{array}$ & & & 0.597 \\
\hline $\begin{array}{l}\text { I have become more callous toward people } \\
\text { since I took this job }\end{array}$ & & & 0.827 \\
\hline $\begin{array}{l}\text { I worry that this job is hardening me } \\
\text { emotionally }\end{array}$ & & & 0.566 \\
\hline $\begin{array}{l}\text { I do not really care what happens to some } \\
\text { recipients whose businesses I deal with. }\end{array}$ & & & 0.724 \\
\hline $\begin{array}{l}\text { I feel recipients blame me for some of their } \\
\text { problems }\end{array}$ & & & 0.606 \\
\hline $\begin{array}{l}\text { Explanatory Percentage of Sub-scales' } \\
\text { Variance }\end{array}$ & 34.5 & 14.9 & 7.3 \\
\hline Total Explained Variance & & & $\% 56.67$ \\
\hline Kaiser-Meyer-Olkin (KMO) & & & 0.886 \\
\hline \multirow[t]{3}{*}{ Bartlett's Test of Sphericity } & nate chi-square & & 1973.961 \\
\hline & & & 231 \\
\hline & & & .000 \\
\hline
\end{tabular}

As a result of the factor analysis of the self-oriented perfectionism variable (Table 4), the four sub-scale statements were excluded because their factor loadings were below 0.50 . 
Table 4: Factor Analysis of Self-Oriented Perfectionism Scale

\begin{tabular}{|c|c|}
\hline \multicolumn{2}{|l|}{ Self-Oriented Perfectionism } \\
\hline I cannot feel at ease until the task that I work on is perfect. & 0.648 \\
\hline One of my goals is to be perfect with everything I do. & 0.660 \\
\hline I strive to be as perfect as possible. & 0.849 \\
\hline It is important to me to be perfect in everything I attempt. & 0.792 \\
\hline I strive to be the best with everything I do. & 0.819 \\
\hline I never accept less than perfection for myself. & 0.636 \\
\hline I am overly concerned about the possibility of finding mistakes with what I do. & 0.796 \\
\hline I am perfectionist when setting my goals. & 0.646 \\
\hline I must always strive to do the best. & 0.800 \\
\hline I set high standard for myself. & 0.650 \\
\hline I must always be successful at work or school. & 0.830 \\
\hline Total Explained Variance & $\% 45.07$ \\
\hline Kaiser-Meyer-Olkin (KMO) & 0.907 \\
\hline Bartlett's Test of Sphericity & 1315.966 \\
\hline s.d. & 105 \\
\hline $\mathrm{P}$ & .000 \\
\hline
\end{tabular}

\section{Burnout level}

According to the Maslach Burnout Inventory, marble employees have a moderate emotional exhaustion level and a high level of depersonalization and personal accomplishment. The level of self-oriented perfectionism is 4.66 in the 7-point Likert system.

\section{Correlation analysis}

The relationship between self-oriented perfectionism and burnout sub-scales was tested using correlation analysis in the study (Table 5).

Table 5: Correlation Analysis Results

\begin{tabular}{lcccc}
\hline Variables & $\mathbf{1}$ & $\mathbf{2}$ & $\mathbf{3}$ & $\mathbf{4}$ \\
\hline 1.Self-oriented Perfectionism & - & & & \\
\hline 2. Emotional Exhaustion & $0.296^{* *}$ & - & & \\
\hline 3. Personal Accomplishment & $0.177^{*}$ & $0.321^{* *}$ & - & \\
\hline 4. Depersonalization & $0.337^{* *}$ & $0.587^{* *}$ & $0.295^{* *}$ & - \\
\hline
\end{tabular}

According to the findings, there is a positive and significant relationship between self-oriented perfectionism and all dimensions of burnout. If the correlation coefficient is between 0 and \pm 0.3 , the strength of the relationship is low; if the coefficient is between \pm 0.3 and \pm 0.7 , the strength of the relationship is medium, and if the coefficient is between \pm 0.7 and \pm 1 , the strength of the relationship is high (Saruhan and Özdemirci, 2016, p. 248). When Table 5 is examined, it is observed that there is a low relationship between self-oriented perfectionism and emotional exhaustion, a low relationship between self-oriented perfectionism and personal accomplishment, and a moderate relationship between selforiented perfectionism and depersonalization. According to the findings obtained, there is a positive and significant relationship between self-oriented perfectionism and emotional exhaustion, personal accomplishment, and depersonalization. Accordingly, it is seen that the $\mathrm{H}_{1}, \mathrm{H}_{2}$, and $\mathrm{H}_{3}$ hypotheses are accepted.

\section{Regression analysis}

The direction and size of the effect between self-oriented perfectionism and emotional exhaustion, personal accomplishment, and depersonalization were tested with regression analysis. Three different models have been established to determine how direction the obtained variables will affect the other variable if they are dependent. 


\section{The effect of self-oriented perfectionism on emotional exhaustion}

Analysis results in which the dependent variable is emotional exhaustion, and the independent variable is self-oriented perfectionism, presented in Table 6. When Table 6 is examined, the probability value (or p-value) of $T$ less than 0.05 shows that the coefficient is statistically significant. A standard beta value of 0.45 indicates that a one standard deviation increase in the level of self-oriented perfectionism increases emotional exhaustion by 0.45 standard deviation.

Table 6: Model results - Self-oriented Perfectionism and Emotional Exhaustion

\begin{tabular}{lllll}
\hline & Beta value & $\begin{array}{l}\text { Standard Beta } \\
\text { value }\end{array}$ & T- value & $\begin{array}{l}\text { T-Test } \\
\text { probability } \\
\text { value }\end{array}$ \\
\hline Coefficients & 0.830 & 0.296 & 4.068 & 0.000 \\
\hline
\end{tabular}

When the F Test results, which tests the significance of the model as a whole, were examined in Table 7 , the founded model was significant since the probability value is less than 0.05 .

Table 7: Diagnostic Test Results

\begin{tabular}{lllllll}
\hline & $\begin{array}{l}\text { Durbin } \\
\text { Watson } \\
\text { value }\end{array}$ & $\begin{array}{l}\text { Adjusted } \\
\text { R- } \\
\text { squared }\end{array}$ & $\begin{array}{l}\text { F- Test } \\
\text { sq Test }\end{array}$ & $\begin{array}{l}\text { Skewness } \\
\text { p- } \\
\text { value }\end{array}$ & $\begin{array}{l}\text { Kurtosis } \\
\text { values of } \\
\text { residuals }\end{array}$ & $\begin{array}{l}\text { values of } \\
\text { residuals }\end{array}$ \\
\hline $\begin{array}{l}\text { Emotional Exhaustion } \\
\text { Self-oriented } \\
\text { Perfectionism }\end{array}$ & 1.415 & 0.082 & 16.549 & .000 & -0.564 & 0.014 \\
\hline
\end{tabular}

Besides, regression assumptions were tested. Firstly, the normal distribution of error terms was examined with the help of kurtosis skewness values. For this value to be considered normal, it must be between +1.5 and -1.5 (Tabachnick and Fidell, 2013). Table 7 shows that the skewness and kurtosis values are in this range.

Another assumption of the regression analysis is that there should be no relationship between the model's error terms (Sevüktekin, 2007, p. 243). While this problem is called autocorrelation, the problem of autocorrelation was investigated with the Durbin-Watson value. While this value between 1.5-2.5 is considered normal (Kalayc1, 2005, p. 267), it is seen in Table 7 that the value is remarkably close to this range.

\section{The effect of self-oriented perfectionism on depersonalization}

Table 8 presents the model's estimation results in which the dependent variable is depersonalization, and the independent variable is self-oriented perfectionism. Table 8 shows that the coefficient is statistically significant. The fact that the standard beta value is 0.34 indicates that one standard deviation increase in the sub-scale of self-oriented perfectionism increases the depersonalization by 0.34 standard deviation.

Table 8: Model Results (Depersonalization - Self-oriented Perfectionism)

\begin{tabular}{lllll}
\hline & Beta value & Standard Beta value & T-value & T-test p-value \\
\hline Coefficients & 1.116 & 0.337 & 4.691 & .000 \\
\hline
\end{tabular}

The skewness and kurtosis values were given in Table 9, and the assumption that the error terms are typically distributed was confirmed. For the problem of autocorrelation, the Durbin-Watson value was examined, and it was found that the value was remarkably close to the range of 1.5-2.5. In addition, the F Test probability value less than 0.05 indicates that the model is significant. 
Table 9: Diagnostic Test Results

\begin{tabular}{lllllll}
\hline & $\begin{array}{l}\text { Durbin } \\
\text { Watson } \\
\text { value }\end{array}$ & $\begin{array}{l}\text { Adjusted R- } \\
\text { squared }\end{array}$ & F- Test & $\begin{array}{l}\text { F Test p- } \\
\text { value }\end{array}$ & $\begin{array}{l}\text { Skewness } \\
\text { values of } \\
\text { residuals }\end{array}$ & $\begin{array}{l}\text { Kurtosis } \\
\text { values of } \\
\text { residuals }\end{array}$ \\
\hline $\begin{array}{l}\text { Depersonalization- } \\
\text { Self-oriented } \\
\text { Perfectionism }\end{array}$ & 1.420 & 0.108 & 22.003 & .000 & -0.451 & 0.287 \\
\hline
\end{tabular}

The effect of self-oriented perfectionism on personal accomplishment

Table 10 presents the model's estimation results where the dependent variable is a personal accomplishment, and the independent variable is perfectionism. When Table 10 was examined, it was seen that the coefficient is statistically significant, and an increase by one standard deviation in the selforiented perfectionism score of the individual increases the personal accomplishment by 0.18 standard deviation.

Table 10: Model Results (Personal Accomplishment - Self-oriented Perfectionism)

\begin{tabular}{lllll}
\hline & Beta value & Standard Beta value & T-value & T-test p-value \\
\hline Coefficients & 0.890 & 0.177 & 2.365 & .019 \\
\hline
\end{tabular}

When Table 11 was examined, it was seen that the residuals are distributed normally. When the Durbin Watson value was examined, it was found that the value was not in the range of 1.5-2.5, and there was a partial relationship between the error terms. The model continued to be interpreted because the model was significant, and the beta value was statistically significant. Besides, the probability value of the $\mathrm{F}$ Test less than 0.05 indicates that the model is significant.

Table 11: Diagnostic Test Results

\begin{tabular}{lllllll}
\hline & $\begin{array}{l}\text { Durbin } \\
\text { Watson } \\
\text { value }\end{array}$ & $\begin{array}{l}\text { Adjusted R- } \\
\text { squared }\end{array}$ & $\begin{array}{l}\text { F- } \\
\text { Test }\end{array}$ & $\begin{array}{l}\text { F Test p- } \\
\text { value }\end{array}$ & $\begin{array}{l}\text { Skewness } \\
\text { values of } \\
\text { residuals }\end{array}$ & $\begin{array}{l}\text { Kurtosis } \\
\text { values of } \\
\text { residuals }\end{array}$ \\
\hline $\begin{array}{l}\text { Personal } \\
\text { accomplishment } \\
\begin{array}{l}\text { Self-oriented } \\
\text { perfectionism }\end{array}\end{array}$ & -0.615 & 0.026 & 5.591 & .019 & 0.084 & -0.433 \\
\hline
\end{tabular}

\section{Results and discussion}

In the literature, the results of studies which shows the complex image in explaining the relationship between perfectionism and burnout display, unclearness of the relationship between different sub-scale of perfectionism and burnout, and perfectionist personality trait's effect on attitudes towards work makes the subject attractive (Childs ve Stoeber 2010). In this study, the relationship between perfectionist personality trait and burnout is investigated. The sample of the study consists of employees in marble enterprises operating in the province of Burdur. According to the results, otheroriented perfectionism and socially prescribed perfectionism, which are sub-scales of perfectionism, were excluded from the research's scope due to their low-reliability level. As a result of the study, a significant and positive relationship was found between self-oriented perfectionism, one of the subscales of perfectionism, emotional exhaustion, depersonalization, and personal accomplishment subscales of burnout. It can be stated that this situation is caused by the self-oriented perfectionists setting challenging goals for themselves and constantly blaming themselves for the cause of failure. The studies reveal that perfectionism has some adverse psychological effects on individuals, such as depression, anxiety disorder, and suicidal thoughts (Özbilir et al., 2015). Flett et al. (1996, p. 143) found that selforiented perfectionism brought some psychological difficulties such as chronic loneliness, shyness, and self-insecurity. It can be stated that the situation in question is quite weary for the person and, after a 
while, pushes the person to burnout. Hill (2013) examined the influence of perfectionism on burnout and found that evaluative concerns perfectionism is a strong predictor.

Seong et al. (2021, p.1) found that general perfectionism predicted longitudinal increases in emotional exhaustion in their study with a sample of 336 secondary school students. As a result of the study conducted by Chang et al. (2011), it was observed that university students' emotional burnout levels increased when their perfectionism tendencies strengthened. Perfectionists are at high risk of burnout because the perfectionist behaviour trait consumes the individual's mental energy. Scott et al. (1997) state that perfectionists have a high degree of workaholism, and workaholics are much more prone to stress. Spending too much time and effort on the job brings terrible health conditions, low life satisfaction, and burnout. Perfectionists hold on to extremely high standards and constantly criticize themselves. In this respect, perfectionism is regarded as a highly effective and mobilizing force, but it also brings various psychological difficulties if the effort fails.

Contrary to some opinions that evaluate perfectionism positively, according to Flett and Hewitt (2006), perfectionists set extremely high standards that are almost impossible to achieve and make an intense effort to achieve them. Thus, perfectionists constantly criticize themselves and focus excessively on their inadequacies. It is known that all styles of perfectionism, positive or negative (adaptive/ maladaptive), push individuals to make an intense effort at work and consume their resources. Intense effort and depleted resources not only increases the level of stress but also increases the burnout risk. The results obtained from the studies carried out on the subject in the literature and the results obtained from this study support a relationship between perfectionism and burnout. (Balevre et al., 2012; Çam et al., 2014; Badawy and Mohamad 2015; Mitchelson and Burns 1998; Appleton et al. 2009 and Chen et al. 2008).

The fact that the current research has a positive relationship with self-oriented perfectionism and all sub-scale burnout necessitates that employees in workplaces should reduce their self-oriented perfectionism. At this point, it is recommended that businesses should offer personal development and psychological consultancy services to employees.

The most important limitation is that the current research is conducted only on a small sample due to financial and time constraints. Besides, the exclusion of other-oriented perfectionism and socially prescribed perfectionism from the analysis due to lack of reliability constitutes another limitation of the research. The relationship between different sub-scales of perfectionism and burnout is also unclear (Childs and Stoeber 2010). It is considered that studies carried out with different samples will clarify the subject. Studies investigating the mediator variables of concepts such as stress, workaholicism, life satisfaction, job satisfaction, or the moderator variables of concepts such as gender, age, and whether businesses provide psychological support services will contribute to the literature.

\section{Peer-review:}

Externally peer-reviewed

\section{Conflict of interests:}

The authors have no conflict of interest to declare.

\section{Grant Support:}

The authors declared that this study has received no financial support 


\section{References}

Adler, A. (1956). The Neurotic Disposition, H. L. Ansbacher and R. R. Ansbacher (Eds.). The Individual Psychology of Alfred Adler (pp. 239-262). New York: Harper

Aghdasi, M. T. (2014). The relationship between perfectionism and burnout in junior-elite athletes international. Journal of Science Culture and Sport (IntJSCS), 2(1), 27-39.

Anshel, M. H., and Mansouri, H. (2005). Influences of perfectionism on motor performance, affect, and causal attributions in response to critical information feedback. Journal of Sport Behavior, 28(2).

Anvari, M., Kalali, N. and Gholipour, A. (2011). How does personality affect on job burnout? International Journal of Trade Economics and Finance, 2(2).

Appleton, P. R., Hall, H. K., and Hill, A. P. (2009). Relations between multi-dimensional perfectionism and burnout in junior-elite male athletes. Psychology of Sport and Exercise, 10(4), 457-465.

Ardiç, K., and Polatci, S. (2009). Tükenmişlik sendromu ve madalyonun öbür yüzü: işle bütünleşme [Burnout syndrome and the other side of medallion: engagement]. Erciyes Üniversitesi İktisadi ve İdari Bilimler Fakültesi Dergisi[Erciyes University Journal of Economics and Administrative Sciences], (32), 2146.

Badawy S. M. and Mohamad M. S. (2015). Perfectionism and job burnout: does religious coping moderate the relationship?. International Journal of Business and Social Research, 5(12).

Balevre, P. S., Cassells, J. and Buzaianu, E. (2012). Professional nursing burnout and irrational thinking: a replication study. Journal for Nurses in Professional Development, 28(1), 2-8.

Burns D. D. (1980). The perfectionist's script for self-defeat. Psychology Today, 34-51.

Büyükateş, V. (2018). Mükemmeliyetçilik, Olumsuz Değerlendirilme Korkusu ve Yaşam Doyumu Arasındaki Ilişkilerin Incelenmesi [The Relationship Between Perfectionism, Fear Of Negative Evaluation And Life Satisfaciton]. Master thesis, Lefkoşa: Near East University.

Cakınberk, A. (2011). Studying the relationship between employees occupational burnout levels and satisfaction of life: a research in private banks. African Journal of Business Management, 5(16), 68256838 .

Çam, Z., Deniz, K. Z. and Kurnaz, A. (2014). Okul tükenmişliği: algılanan sosyal destek, mükemmeliyetçilik ve stres değişkenlerine dayalı bir yapısal eşitlik modeli sınaması [School burnout: testing a structural equation model based on percieved social support, perfectionism and stress variables]. Eğitim ve Bilim [Education and Science], 39, (173).

Cenkseven Önder, F. and Kırdök, O. (2009). Ön ergenlerin olumlu-olumsuz mükemmeliyetçilik düzeylerinin anne-çocuk ilişkisini algılamaları açısından incelenmesi [Examining positive and negative perfectionism levels with respect to early adolescents' perception of mother-child relation]. Mersin Üniversitesi Eğitim Fakültesi Dergisi [Mersin University Journal of The Faculty of Education], 5(2), 263-274.

Chang, E. C., Lin, N. J., Herringshaw, A. J., Sanna, L. J., Fabian, C. G., Perera, M. J., et al. (2011). Understanding the link between perfectionism and adjustment in college students: examining the role of maximizing. Personality and Individual Differences, 50(7), 1074-1078.

Chen, L. H., Kee, Y. H., Chen, M. Y. and Tsai, Y. M. (2008). Relation of perfectionism with athletes' burnout: further examination. Perceptual and Motor Skills, 106, 811-820.

Childs , J.H. and Stoeber, J. (2012). Do you want me to be perfect? two longitudinal studies on socially prescribed perfectionism. Stress And Burnout In The Workplace, Work \& Stress, 26 (4), 347-364.

Childs, J. H., and Stoeber, J. (2010). Self-oriented, other-oriented, and socially prescribed perfectionism in employees: relationships with burnout and engagement. Journal of Workplace Behavioral Health, 25(4), 269-281.

Cho, H. H., and Kang, J. M. (2017). Factors influencing clinical practice burnout in student nurses. Child Health Nursing Research, 23(2), 199-206.

Çiçek, B. and Aknar, A. (2019). Kişilik özelliklerinin tükenmişlik ve presenteizm davranışları üzerindeki etkisi [The effect of personality traits on burnout and presenteeism behaviors]. Üçüncü Sektör Sosyal Ekonomi Dergisi [Third Sector Social Economic Review], 54(3), 1234-1258. 
Çimen, M. (2000). Türk Silahlı Kuvvetleri Sağlık Personelinin Tükenmişlik, İş Doyumu, Kuruma Bağlılık ve İşten Ayrılma Niyetlerine İlişkin Bir Alan Araştırması [A field study for burnout, job satisfaction, organisational commitment and intention to leave of health personnel in Turkish Armed Forces]. Doctoral Thesis, Ankara: T. C. Genelkurmay Başkanlığı Gülhane Askeri Tıp Akademisi Sağlık Bilimleri Enstitüsü.

Demirci, E. and Çepikkurt, F. (2018). Examination of the relationship between passion, perfectionism and burnout in athletes. Universal Journal of Educational Research. 6(6), 1252-1259.

Demirezen, M., and Şenol, Y. (2020). Mermer sektöründe çalışan işçilerde stres düzeyi ve tükenmişliği etkileyen faktörler: bir fabrika örneği [Stress level and burnout in workers in the marble business: example of a factory]. Kocatepe Tıp Dergisi [Kocatepe Medical Journal], 21(2), 157-161.

D'Souza, F., Egan , S.J. and Rees, C.S. (2011). The relationship between perfectionism, stress and burnout in clinical psychologists. Behaviour Change, 28 (1), 17-28.

Eren, S. and Günlü Küçükaltan, E. (2017). Mükemmeliyetçiliğin iş performansına etkileri: aşçllar üzerine bir araştırma [Effects of perfectionism to job performance: an investigation on chefs]. Anatolia: Turizm Araştırmaları Dergisi [Anatolia: A Journal of Tourism Research], 28 (2) , 281-292 . DOI: 10.17123 /atad.362640

Ergin, C. (1992). Doktor ve Hemşirelerde Tükenmişlik ve Maslach Tükenmişlik Ölçeğinin Uyarlaması, VII. Ulusal Psikoloji Kongresi Bilimsel Çalışmaları El Kitabı, 143-154.

Fairlie, P. and Flett, G.L. (2003). Perfectionism At Work: Impacts On Burnout, Job Satisfaction, And Depression. Poster presented at the 111th Annual Convention of the American Psychological Association, Toronto, Ontario, Canada.

Flett, G. Hewitt, P. and De Rosa, T. (1996). Dimensions of perfectionism, psychosocial adjustment and social skills. Personality and Individual Differences, 20(2), 143-150.

Flett, G.L. and Hewitt, P.L. (2006). Positive versus negative perfectionism in psychopathology. Behaviour Modification, 30, 472-495.

Freudenberger, H. (1974). Staff burnout. Journal of Social Issues, 30, 159-165.

Frost R. O., Marten P., Lahart C. and Rosenblate R. (1990). The dimensions of perfectionism. Cognit Ther Res, 14, 449-68.

Gürbüz, S. and Şahin F. (2016). Sosyal Bilimlerde Araştırma Yöntemleri: Felsefe - Yöntem-Analiz. Ankara: Seçkin Yayınları.

Hall, H. K. (2006). Perfectionism: A Hallmark Quality Of World Class Performers, Or A Psychological İmpediment To Athletic Development, In Perspectives On Sport And Exercise Psychology: Essential Processes For Attaining Peak Performance, Edited by: Hackfort, D. and Tenenbaum, G. 1, 178211. Aachen, , Germany: Meyer and Meyer.

Hewitt P. L. and Flett G. L. (2004). The cognitive and treatment aspects of perfectionism: introduction to the special issue. J Ration Emot Cogn Behav Ther, 22, 233-40.

Hewitt P.L. and Flett G.L. (1991). Dimesion of perfectionism in unipolar depression. J Abnorm Psychol, 100, 98-101.

Hewitt, P. L., Flett, G. L. (1989). The multidimentional perfectionism scale: development and validation. Can Psychol, 30, 339-360.

Hill A. P. and Appleton, P. R. (2011). The predictive ability of the frequency of perfectionistic cognitions, self-oriented perfectionism, and socially prescribed perfectionism in relation to symptoms of burnout in youth rugby players. Journal of Sports Sciences, 29(7), 695-703.

Hill, A. P. and Curran, T. (2015). Multi-dimensional perfectionism and burnout: a meta-analysis. Personality and Social Psychology Review.

Hill, A. P., Hall, H. K. and Appleton, P. R. (2010). Perfectionism and athlete burnout in junior elite athletes: the mediating role of coping tendencies. Anxiety, Stress, E Coping, 23 (4), 415-430.

Hill, A. P. (2013). Perfectionism and burnout in junior soccer players: a test of the $2 \times 2$ model of dispositional perfectionism. Journal of Sport and Exercise Psychology, 35 (1), 18-29. doi: $10.1123 /$ jsep.35.1.18.

Horney, K. (1950). Neurosis and Human Growth, New York: Norton. 
Hralbuik, C. (2009). The Dark Side of Goal Setting: Examining The Relationship Between Perfectionism and Maximum versus Typical Employee Performance, Doctoral thesis. Toronto: Toronto University School of Joseph L. Rothman.

Kakırman, A. and Birsel M. (2015). An study applied in banking sector about the relationship between perfectionism and burnout. Siyaset, Ekonomi ve Yönetim Araştırmaları Dergisi, 3(3).

Kalaycı, Ş. (2005). SPSS Uygulamalı Çok Değişkenli Istatistik Teknikleri, Ankara: Asil Yayın Dağıtım.

Kanten, P. and Yeşiltaş, M., (2015). The effects of positive and negative perfectionism on work engagement, psychological well-being and emotional exhaustion. Procedia Economics and Finance, 23: 1367 - 1375.

Lazarus, R.S. (1999). Stress And Emotion: A New Synthesis, New York: Springer.

Lee, R. T. and B. E. Ashforth (1993). A further examination of managerial burnout: toward an integrated model. Journal of Organizational Behavior, 14, 3-20.

Maslach, C. and Jackson, S. (1981). The measurement of experienced burnout. Journal of Organizational Behaviour, 2(2), 99-113.

Maslach, C. and Jackson, S. E. (1986). Maslach Burnout Inventory (2nd Ed.) Palo Alto, CA: Consulting Psychologist Press.

Maslach, C., Schaufeli, W. and Leiter, M. (2001). Job burnout. Annual Review Psychology, 52, 397-422.

Mermer Şehri Burdur, http://www.burdur.gov.tr/mermer-sehri-burdur, (Retrieved on 05.05.2019)

Mitchelson, J. K., and Burns, L. R. (1998). Career mothers and perfectionism: stress at work and at home. Personality and Individual Differences, 25(3), 477-485.

Mor, S., Hy, D.I. and Flett, G.L. (1995). Perfectionism, control, and components of performance anxiety in professional artists. Cognitive Therapy and Research, 19: 207-225.

Oral, M. (1999). The Relationship Between Dimensions of Perfectionism, Stressful Life Events and Depressive Symptoms in University Students' A Test Of Diathesis-Stress Model Of Depression'. Master Thesis, Ankara: Orta Doğu Teknik Üniversitesi.

Özbilir, T., Day, A. D., Catano, V. M. (2015). Perfectionism at work: an investigation of adaptive and maladaptive perfectionism in the workplace among canadian and turkish employees. Applied Psychology: An International Review, 64 (1), 252-280.

Rice, K. G. and Dwello, J.P. (2002). Perfectionism and selfdevelopment: implications for college adjustment. Journal of Counselling \& Development, 80: 194-195.

Sakal, Ö. and Yıldız, S. (2017). Takipçi mükemmeliyetçiliği ile duygusal tükenmişlik arasindaki ilişkide psikolojik iyi oluş ve liderlik tarzlarinin rolü [The roles of psychological well-being and leadership styles in the relationship between follower perfectionism and emotional exhaustion]. International Journal of Business, Economics and Management Perspectives, 2 (7), 37-57.

Saruhan, Ş. C. and Özdemirci, A. (2016). Bilim, Felsefe ve Metodoloji. 4. Press. İstanbul: Beta Press.

Scott, K., Moore, K., and Miceli, M. (1997). An exploration of the meaning and consequences of workaholism. Human Relations, 50, 287-314.

Seong, H., Lee, S. and Chang, E. (2021). Perfectionism and academic burnout: longitudinal extension of the bifactor model of perfectionism. Personality and Individual Differences, 172, 110589.

Sevüktekin, M. (2007). Ekonometrik Zaman Serileri Analizi, Ankara: Nobel Yayınevi.

Shafran, R., Cooper, Z., and Fairburn, C. G. (2002). Clinical perfectionism: a cognitive-behavioural analysis. Behaviour Research and Therapy, 40(7), 773-791.

Sherry, S.B., Hewitt, P.L., Sherry, D.L., Flett, G.L. and Graham, A.R. (2010). Perfectionism dimensions and research productivity in psychology professors: 1mplications for understanding the (mal) adaptiveness of perfectionism. Canadian Journal of Behavioural Science, 42, 273- 283.

Slaney, R. B., Rice, K. G., Mobley, M., Trippi, J. and Ashby, J. S. (2001). The revised almost perfect scale. Measurement and Evaluation in Counseling and Development, 34 (3), 130-146.

Stoeber, J. and Eysenck, M.W. (2008). Perfectionism and efficiancy accuracy, response bias and invested time in proof reading performance. Journal of Research in Personality, 42: 1673-1678. 
Stoeber, J. and Rennert, D. (2008). Perfectionism in school teachers: relations with stress appraisals, coping styles, and burnout. Anxiety, Stress, and Coping, 21(1), 37-53.

Stoeber, J., Davis, C.R. and Townley, J. (2013). Perfectionism and workaholism in employees: the role of work motivation. Personality and Individual Differences, 55: 733-738.

Tabachnick, B. G. and Fidell, L. S. (2013). Using Multivariate Statistics. (6th ed.) Boston: Pearson.

Tashman, L. S., Tenenbaum, G. and Eklund, R. (2010). The effect of perceived stress on the relationship between perfectionism and burnout in coaches. Anxiety, Stress, \& Coping, 23(2), 195-212.

Tziner, A. and Tanami, M. (2013). Examining the links between attachment, perfectionism, and job motivation potential with job engagement and workalcoholism. Journal of Work and Organizational Psychology, 29: 65-74.

Wittenberg, K.J. and Norcross, J.C. (2001). Practitioner perfectionism: relationship to ambiguity tolerance and work satisfaction. Journal of Clinical Psychology, 57, 1543-1550.

Wright, T. A., and Bonett, D. G. (1997). The contribution of burnout to work performance. Journal of Organizational Behavior: The International Journal of Industrial, Occupational and Organizational Psychology and Behavior, 18(5), 491-499.

Zhang, Y., Gan, Y., and Cham, H. (2007). Perfectionism, academic burnout and engagement among Chinese college students: a structural equation modeling analysis. Personality and Individual Differences, 43(6), 1529-1540. 